\title{
Report on excavation of a shell mound site at Mandjungaar, western Cape York Peninsula
}

\author{
Michael Morrison*, Chantal Wight and Emily Evans \\ College of Humanities and Social Sciences, Flinders University, GPO Box 2100, Adelaide, South Australia 5001, Australia \\ * Corresponding author Mick.Morrison@flinders.edu.au
}

\begin{abstract}
This report presents results of excavation and analysis of a shell mound deposit at Mandjungaar, near Weipa, Cape York Peninsula. This study was initiated as a cultural heritage management project focused on a shell mound damaged by unauthorised clearing of access tracks. This study included a small research component to establish a baseline understanding of longer-term use history of the Mandjungaar area at the request of Ndrua'angayth custodians. This included excavation and analysis of a test pit at the site. Results of the study are presented and contextualised in relation to previous research on the Weipa Peninsula in order to expand our understanding of the wider cultural history of the southern Weipa Peninsula. These results provide further support for the assertion that shell mound formation in the Albatross Bay region involved food production activities that were strategically focused on estuarine mud and sandflat ecosystems. In doing so, this dataset provides additional support for the previously proposed niche production model of shell mound formation.
\end{abstract}

\section{Introduction}

Mounded shell matrix sites, or shell mounds, have been observed across the northern Australian coastline and provide a unique and high resolution record of aspects of Aboriginal lifeways through the mid-to-late Holocene (Figure 1). A number of researchers have proposed that mounds represent intensive use of a narrow range of coastal resources, most notably, estuarine shellfish species (Bourke 2005, 2012; Faulkner 2009, 2013; Morrison 2003, 2013a, 2015; Veitch 1999). Such arguments are supported by field data that show that mound deposits are often dominated by one or two species of shellfish - most commonly the intertidal bivalve Tegillarca granosa (syn. Anadara granosa) - and limited proportions of other faunal evidence (see Faulkner 2013). These arguments are typically based on local datasets on mound composition and chronology, yet despite this, and as Ulm (2011:455) highlights, there remains significant gaps in both local and regional datasets in northern Australia due to the extensive length of the coastline, a small number of active researchers and the short history of the discipline in Australia.

A considerable proportion of research on mound sites has occurred at Weipa, on the western coast of Cape York Peninsula (Figure 1), where one of the largest assemblages of such sites occurs (Bailey 1994, 1999; Morrison 2013b). Over 500 mound sites have been documented in the Weipa area across a wide range of geomorphic and ecological settings (Bailey 1994; Morrison 2013b), with a temporal range of approximately $4000 \mathrm{cal} \mathrm{BP}$ to the late 1800 s (Holdaway et al. 2017; Morrison 2014). Yet despite intensive research, there remain many localities where shell mounds are known to exist, but where little or no sampling has taken place. This paper reports on the results of excavations at one such location, the clan estate of Mandjungaar, located on the southern Weipa Peninsula (Figure 2). The original study was commissioned by the former bauxite mining company Comalco Aluminium Ltd (now Rio Tinto) in 2004, following unauthorised access track maintenance that caused minor damage to a previously recorded shell mound. Ndrua'angayth custodians requested archaeological investigations, including excavation and radiocarbon dating, ahead of site rehabilitation works. Although undertaken as a cultural heritage management project, this study contributes new datasets relevant to understanding late Holocene settlement patterns, economies and occupation chronologies on the Weipa Peninsula. Mandjungaar is approximately mid-way between two other intensively studied areas, the well-known Kwamter mound (Bailey 1977; Stone 1992, 1995; Wright 1971), as well as large mound complexes near Wathayn and Ndhinggwulung (Figure 1), that have been the focus of a recent and ongoing major research program (Brockwell et al. 2017; Fanning et al. 2018; Holdaway et al. 2017; Shiner et al. 2013). This paper reports on the research design and results of work at Mandjungaar, before considering these in relation to other work undertaken on the Weipa Peninsula, and across the Albatross Bay catchment more generally.

\section{Previous Research}

Archaeological research at Weipa commenced in the 1960s as part of a wider reconnaissance program sponsored by the then Australian Institute of Aboriginal Studies (AIAS), with fieldwork undertaken by Richard Wright (Wright 1963, 1971) and later, his doctoral student Geoff Bailey (Bailey 1975, 1977). This included field surveys to understand the distribution and morphology of shell mound sites across the wider Albatross Bay catchment, as well as test excavations on several mound sites, with the wider aim of determining whether these sites were of anthropogenic or natural formation (see Bailey 1977). The Kwamter mound, so named after the wider Ndrua'angayth clan estate in which the site is located, was where archaeological research initially established that the Weipa shell mounds were formed through the activities of people (Figure 2). Excavations by Wright (1971) and Bailey $(1975,1977)$ demonstrated the presence of limited amounts of fish bone, mammal bone, and stone and bone artefacts throughout poorly stratified deposits comprised primarily of shellfish ( $T$. granosa) with variable proportions of soil and ash. Radiocarbon determinations showed nearbasal ages of 1049-1269 cal BP (SUA-149) for the site (SM393) (Bailey 1977) (see Morrison 2014 for calibration data; site numbers after Morrison 2013a). 


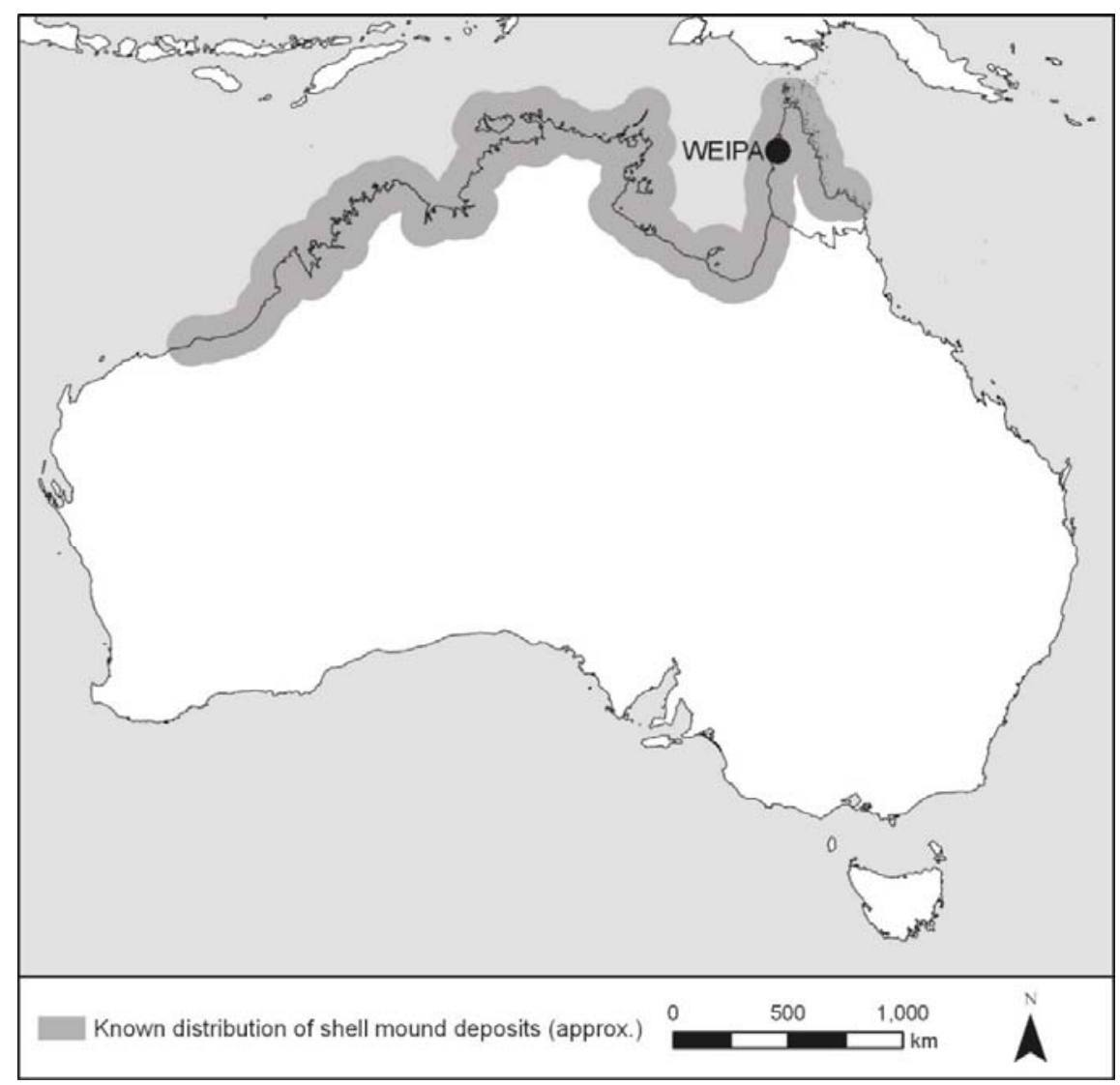

Figure 1. Location map showing the known distribution of shell mound deposits in northern Australia. Note that oyster-dominated shell mounds occur on the central Queensland coast (Smith 2016; Ulm 2002).

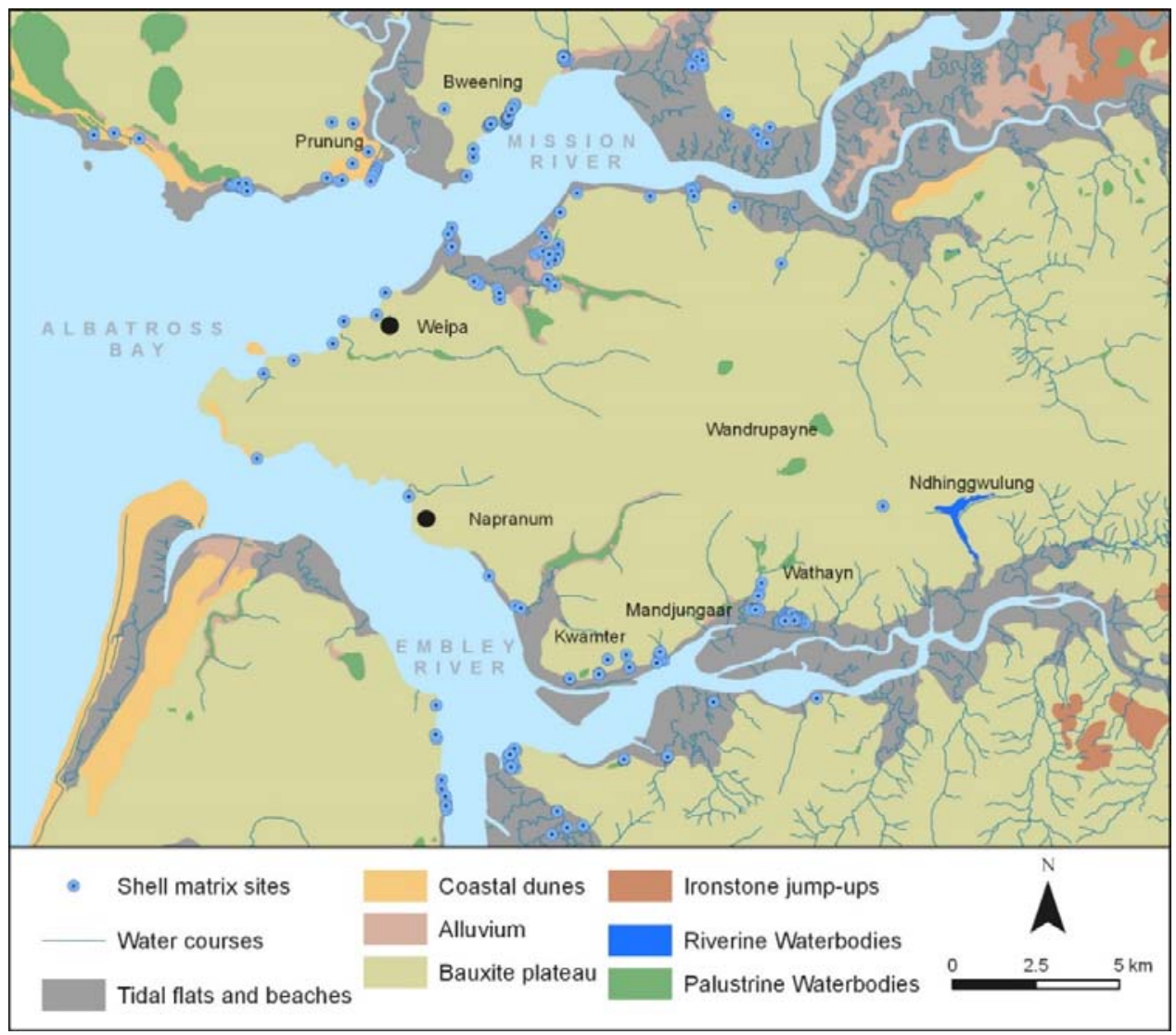

Figure 2. Landscapes and archaeology of the Weipa Peninsula. 
In the early 2000s, Roger Cribb initiated a cultural heritage study of shell mound sites throughout the Albatross Bay catchment, in partnership with the former Napranum Aboriginal Community Council, Napranum Aboriginal Corporation and local Aboriginal custodians. This followed on from a range of prior cultural heritage studies he had undertaken as part of work towards the signing and eventual implementation of the Western Cape Communities Coexistence Agreement (WCCCA) - an Indigenous Land Use Agreement between some local Indigenous custodians, local mining interests and other stakeholders (Cribb 1996). A comprehensive field survey of shell mound deposits across the wider catchment added to previous regional shell mound inventories created by Bailey $(1975,1993)$ and formed the basis of doctoral research by Morrison (2010, 2013b). Following the implementation of cultural heritage provisions within the WCCCA in the early 2000s, the region has seen a proliferation of archaeological surveys that have transformed our understanding of the regional archaeological record (Shiner and Morrison 2009). Culturally modified trees, earth mounds, stone artefact deposits and a wide range of postcontact heritage places have been reported and investigated. Additionally, a new program of research focusing on shell matrix sites was initiated on the north Mission River (Figure 2 ), with the aim of obtaining comparative samples and radiocarbon determinations on shell matrix deposits across two discrete study areas, at Bweening (Morrison 2013a) and Prunung (Morrison 2015) (Figure 2).

More recently, several new archaeological research programs have been undertaken on the southern Weipa Peninsula, and within the Wathayn Clan Estate. Shiner et al. (2013) undertook a research project targeting shell matrix sites in collaboration with Rio Tinto and Wathayn Traditional Owners. In an intensive study of four shell matrix sites located at the Wathayn outstation, they determined a high degree of variability existed between shell matrix sites, including hiatus periods in the formation of some mound sites. An expanded program of research focused on shell mound features followed, and sought to understand the temporal and spatial variability of a large number of sites at one locality, encompassing both shell matrix deposits (Fanning et al. 2018; Holdaway et al. 2017) and earth mounds (Brockwell et al. 2017). This required a major program of field sampling to obtain stratigraphic profiles, column samples and radiocarbon determinations from 70 shell matrix features within a study area with at least 158 identified sites and some 212 radiocarbon determinations (Holdaway et al. 2017). This work demonstrated that mound building commenced on the southern Weipa Peninsula at $\sim 4000$ cal BP and through until the past 500 years, but with little consistency in mound accumulation rates between mounds or within particular phases (Holdaway et al. 2017:18).

Until recently, only limited palaeoenvironmental research had been conducted on mainland Cape York Peninsula via work to the east of Coen (Luly et al. 2006) and in the Laura region (Stephens and Head 1995). This has constrained our ability to understand possible relationships between Holocene archaeological and palaeoenvironmental trends on western Cape York Peninsula. A recent investigation at Wandrupayne (Big Willum Swamp), a perennial swamp approximately $8 \mathrm{~km}$ to the northeast of Mandjungaar, provided the first robust published terrestrial record of vegetation and fire histories for this region. Stevenson et al. (2015) obtained three sediment cores at Wandrupayne as part of research investigating the associations between shell mound formation and environmental change on the Weipa Peninsula. Results indicate initial swamp formation from 8000 cal BP with the establishment of an open water body with a margin featuring sedge, herbs and grasses, thin strands of Melaleuca spp., and low proportions of broadleaf taxa associated with monsoon vine forest thickets (Stevenson et al. 2015:26). Low sedimentation rates through the period $4700-2200 \mathrm{cal}$ BP are interpreted as evidence of a contraction of the water body and more ephemeral conditions through this period, with the establishment of the swamp as a permanent free-standing water body only after $2200 \mathrm{cal} \mathrm{BP}$, with present water levels reached by $600-400 \mathrm{cal} \mathrm{BP}$. The vegetation record indicates a similar range of taxa to those present in the area today, with abundant Eucalyptus spp. and Melaleuca spp., although the authors suggest that the understory was more diverse in the past. Wood charcoal is present throughout the record, suggesting the ongoing presence of wild fires, but a pronounced period of burning is present at c. $1000 \mathrm{cal} \mathrm{BP}$ and is associated with subtle vegetation shifts (Stevenson et al. 2015:27). A second increase in wood charcoal proportions occurs in the late nineteenth and early twentieth centuries, and this is argued to be linked to altered fire regimes associated with the arrival of Europeans.

\section{Mandjungaar}

The Mandjungaar area is located approximately $8 \mathrm{~km}$ southeast of the community of Napranum (Figure 2). In late 2004, Ndrua'angayth custodians were notified by Comalco Aluminium Ltd heritage staff about an incident involving damage to a recorded shell mound site within a mining lease at Mandjungaar. Following a site visit and discussions with Comalco staff, custodians requested that a salvage excavation be carried out in order to obtain information about the damaged site and to enable community members to have the damage cleaned up. A small consultancy was commissioned by Comalco which aimed broadly to document the extent of damage to cultural heritage sites in the area along with a limited program of excavation and analysis in order to gain some understanding of the area's cultural history. This work was requested and supervised by Ndrua'angayth custodians including Mrs Thelma Coconut, Mrs Beatrice Gordon and $\mathrm{Mr}$ Stanley Coconut (Figure 3).

The landscapes near Mandjungaar are fairly typical of those around the Weipa Peninsula and very similar to those at Kwamter, located a few kilometres downstream (Figure 2). A broad homogenous bauxite plateau terminates some $250 \mathrm{~m}$ from the modern coastline, with a widespread Eucalyptus tetradonta-dominant woodland (Figure 4). A low broad sand dune (possibly a relict beach ridge) appears to overlie the southern margin of this plateau at Mandjungaar, and fine sandy sediments characterise the substrate along the plateau margin. With an increase in sandy sediment there is also a shift towards dry notophyll vine forest species, and the wide distribution of this behind the coastal wetlands suggests this sandy deposit occurs over a large area (Figure 4). Immediately behind the mangrove zone, a more distinct shore-parallel sand ridge occurs with dense dry vine forest. A seasonal freshwater creek passes between these ridges and forms a small area of freshwater swamp where it cuts through to the coast. A large but discontinuous series of wetlands and associated Melaleuca spp. forests also occur in the area. 


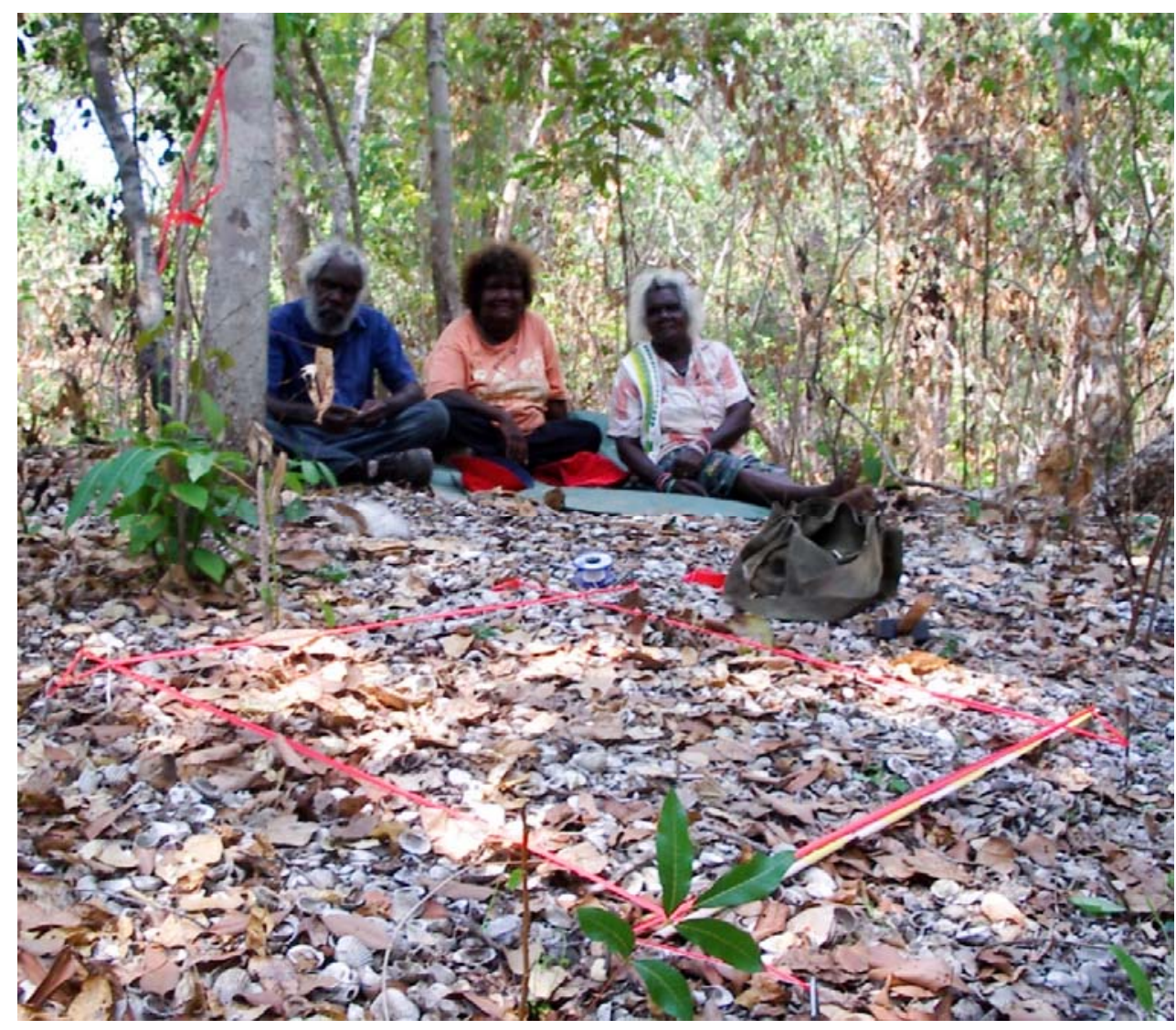

Figure 3. Ndrua'angayth custodians, (L-R) Mr Stanley Coconut, Mrs Thelma Coconut and Mrs Beatrice Gordon at commencement of excavation of SM-217b (Photograph: Michael Morrison, October 2004).

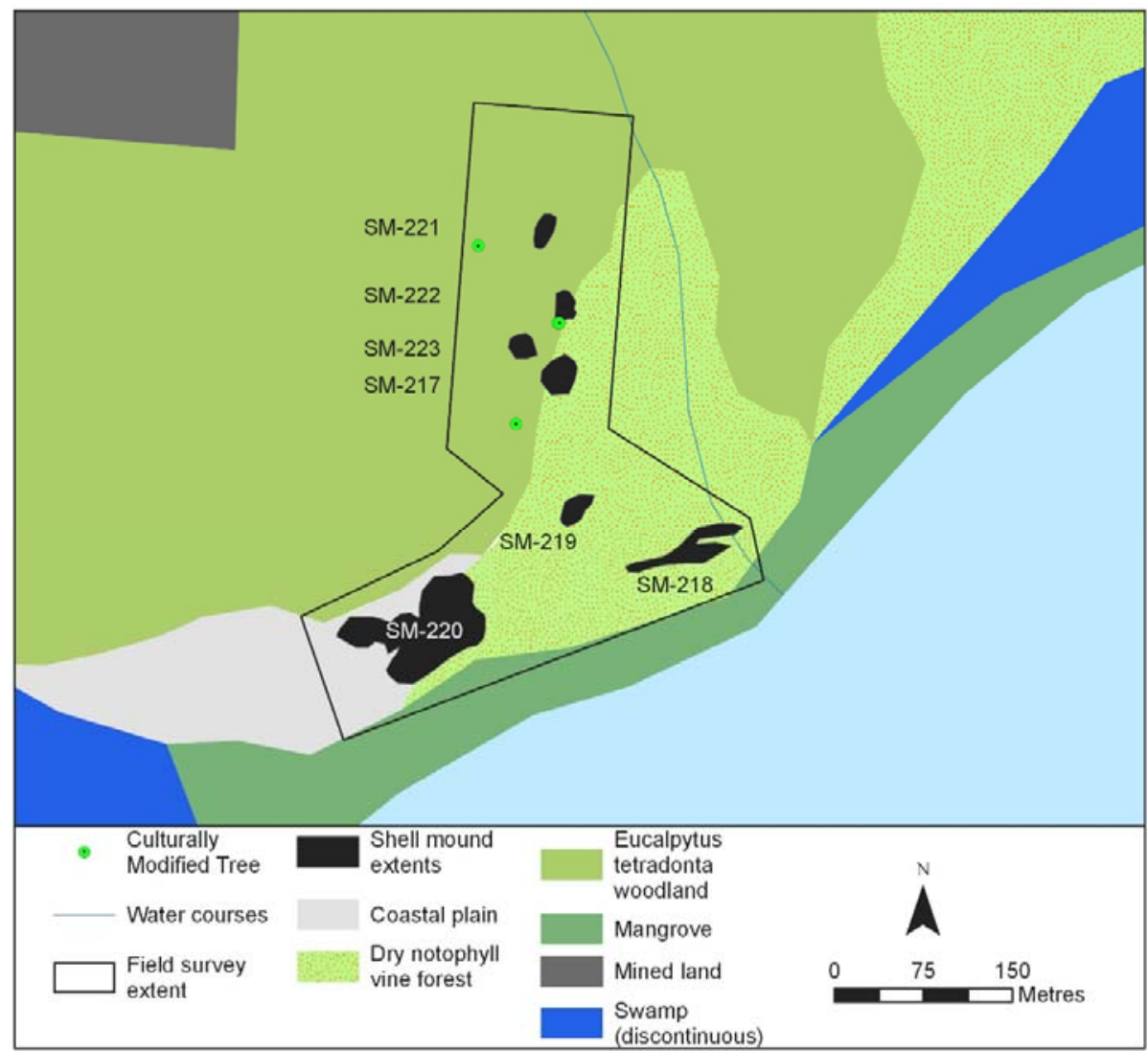

Figure 4. The Mandjungaar study area. 
Historical records and contemporary oral histories provide important context for some of the ways in which the Mandjungaar locality has been used through the twentieth century. Diaries kept by several Superintendents of the second Weipa mission, located at what is now Napranum (Figure 2), mentions 'Manjunga' multiple times indicating this was a destination that was regularly visited by members of the Aboriginal community who at that time largely resided at the mission. Eleven references to visits to Mandjungaar are reported between 1934 and 1936 (McKay 1934, 1935; Winn 1936), all of which took place between January and March at the height of the monsoon. Most of these visits appear to have been part of a wider practice that is well-documented at this time, whereby mission residents travelled away from the settlement for weeks at a time, and often returned with food such as sugarbag (wild honey), game or shellfish that could be exchanged at the mission store (see Morrison et al. 2010). While only passing mention is made, multiple named individuals are reported to have visited the area, and importantly, include the immediate kin of the senior custodians who initiated the current project. One journal entry (McKay 23 February 1934) provides some added detail for a visit by a larger party including the Superintendent, his wife and Aboriginal Councillors for the village:

Mother, Councillors and Self went in punt to "Manjunga" in Punt, killed the two pigs - returning $8.15 \mathrm{pm}$. Village were given one pig to share. Councillors given charge of the sharing.

The consistent timing of these visits during the wet season hints at the possibility that this place was preferred at this time, possibly because specific resources could be obtained. Its close proximity to a spring and wetlands may also be a factor as these represent a focus for food production activities targeting birds, fish and a wide range of plants and tubers.

Interviews with senior custodians Mrs Thelma Coconut, Mr Stanley Coconut and Mrs Beatrice Gordon (Figure 3), and conducted by Morrison (Morrison, Unpublished Field Notes, 2004), indicate continued visits to this area after the 1930s. Mrs Gordon, for example, recounted that her family regularly walked along a track from the former Weipa mission site at Jessica Point and across to Mandjungaar where there was a reliable ('everlasting') spring. They often stopped to rest for a few hours or overnight, while en route to Wathayn further to the west (Figure 2). These trips occurred through at least the period of the 1940s-1960s, prior to large-scale mining activity, which by all accounts severely curtailed the access of custodians to homelands along the southern Weipa Peninsula. Despite that, younger Ndrua'angayth people suggested that they regularly walked from Napranum and across active mining leases to access hunting areas on their homelands at Mandjungaar and Wathayn, leaving before dawn and returning after dark, and often laden with pigs, wallabies, water birds and more. Several outstations were established in the area from the 1970s, and one located at Wathayn remains in regular use today and represents a primary base for hunting, fishing and gathering activities for Ndrua'angayth families and many other community members.

\section{Methods}

Limited field surveys were undertaken across a small area surrounding the mound complex that was the focus of this study. While these surveys provided useful context for the excavation, they took place during a single morning and as such results should only be taken as a preliminary indication of the characteristics of the archaeological record in this area.

Excavation and analysis methods were essentially the same as those used on a number of other excavations in the region (Morrison 2013a, 2015). The general process involved excavating observed stratigraphic layers in $4-6 \mathrm{~cm}$ arbitrary excavation units (XUs), by hand. All excavated materials per excavation unit were weighed, and screened through a $7 \mathrm{~mm}$ and $2 \mathrm{~mm}$ nested sieve with catch tray. While Senior Custodians requested the excavations, they also stipulated that disturbance to the mound be minimised. It was agreed that two test pits be excavated. One, a $0.5 \mathrm{~m} \times 0.5 \mathrm{~m}$ pit (SM-217a), was excavated to the east of the damaged shell mound site and on an area that had been disturbed by earth moving equipment. The aim of this was to assess the depth and stratigraphic integrity of any remaining deposit beneath the area that had been cleared. A second $1 \mathrm{~m} \times 1 \mathrm{~m}$ pit (SM-217b) was excavated on the gently sloping upper surface of the mound.

Initial analysis of $7 \mathrm{~mm}$ residues were carried out over a period of four days in Napranum by Morrison working with a group of female custodians. The primary aim of the analysis was to simply quantify the various elements of the excavated samples by both count and weight, and used the same methods and diagnostic criteria as Morrison (2013a). Molluscs were categorised firstly as to whether they were diagnostic or nondiagnostic, with the former including those that could be used to estimate the minimum number of individual specimens (MNI) for each species. For example, for T. granosa and other bivalves, those fragments that had a complete valve hinge were counted as one valve. Similarly, with Nerita balteata (syn. Nerita lineata, or the mangrove snail) and other gastropods, diagnostic specimens were those with a complete inductura, umbilicus and aperture structure.

A sampling strategy was used to calculate the MNI of $T$. granosa due to the very large proportions of this species recovered, and the fact that custodians required that the site be backfilled with excavated materials. To achieve this, all diagnostic $T$. granosa valves were removed from $7 \mathrm{~mm}$ sieve residues by Elders during the initial field sorting. These were weighed, and a $20 \%$ arbitrary subsample (by weight) was removed for detailed quantification. The $T$. granosa subsample was then quantified via MNI methods, and all $T$. granosa were set aside. This presented analytical problems when comparing $T$. granosa MNI with that of other species not subject to such sampling procedures. To address this, and ensure a standardised dataset was created, the valve count and weight of the T. granosa subsample was used to calculate a mean $T$. granosa valve weight per excavation unit, an approach necessary due to variations in the degree of shell fragmentation between excavation units. Mean valve weight for the T. granosa subsamples was then used to estimate the number of valves present within the unquantified T. granosa sample, and then divided in half to arrive at the estimated total unit MNI. While not an ideal approach, it allowed for community concerns about site damage to be immediately addressed and the site to be properly rehabilitated. All other species recovered were fully quantified and not subject to this form of sampling. Similar sampling approaches have been used on T. granosa subsamples recovered in excavations from other shell matrix sites in the Weipa region (Morrison 2013a, 2015). 
Three samples of $T$. granosa were retrieved for radiocarbon dating from the trench wall after the excavation was completed. The field sampling procedure used was to identify the sample location (a $5 \mathrm{~cm}$ area) and remove and inspect single valves of $T$. granosa from the pit wall. The valves selected were those with the least visible weathering or breakage. Samples were double-bagged once 20-30g were collected (3-5 shells). While not optimal, this procedure was necessary as funds for AMS dating of single valves was not available. Conventional Liquid Scintillation Counting (LSC) was undertaken at the Waikato Radiocarbon Dating Laboratory and samples were subject to standard pretreatment procedures for marine shell. All conventional radiocarbon ages (CRAs) were calibrated with CALIB version 7.1 (Stuiver et al. 2005) using the Marine13 calibration curve (Reimer et al. 2013). Marine reservoir correction factors have an important influence on interpretation of calibrated determinations on marine shellfish (Ulm 2002). A local $\Delta R$ value of $-103 \pm 16$ radiocarbon years (Ulm 2010) is used here in preference to other values (e.g. Petchey et al. 2013; Rhodes et al. 1980) and as per other recent work in the region (Holdaway et al. 2017; Morrison 2014). All calibrated radiocarbon ages are presented at the $2 \sigma$ (95\% confidence) level and individual ages are given as calibrated age-ranges.

\section{Results \\ Field Surveys}

Field surveys in the Mandjungaar study area identified seven shell matrix sites, including five shell mounds and two shell scatters (Table 1), as well as three culturally modified trees (Figure 4). The culturally modified trees identified included a single 'guama' scar and two sugarbag scars, one of which had been felled. 'Guama' is a Thanakwithi word (Richard Barkley, pers. comm., 2004) used to describe what are referred to elsewhere as a "palette or resin bat made of ironwood [Erythrophleum chlorostachys, the Cooktown Ironwood], with a wallaby incisor set in its handle, which was used for smoothing heated resin or wax and for engraving' (Sutton 1994:48). The axe-cut scars are associated with the extraction of sugarbag, or wild honey, and are strongly suggestive of post-contact residential food production which is well-documented on the Weipa Peninsula (Morrison et al. 2010; Morrison and Shepard 2013).

The identified shell matrix deposits were distributed across a $350 \mathrm{~m} \times 400 \mathrm{~m}$ area (Figure 4, Table 1). These sites include two non-mounded deposits, one of which (SM-221) has been moderately disturbed with shell fragments noted to occur in spoil heaps along both sides of the cleared access track. The second non-mounded site (SM-222) was relatively intact and occurs adjacent to two of the culturally modified trees. Two shell mounds were recorded in this area; the first of these is the damaged site, SM-217. This mound is a maximum of $1.2 \mathrm{~m}$ in height and $30 \mathrm{~m} \mathrm{x} 40 \mathrm{~m}$ in area, with a gently sloping dome-shaped surface profile. The total area covered by continuous shell matrix deposit is approximately $33 \mathrm{~m} \times 30 \mathrm{~m}$, with the area of distinct mounded deposit only $20 \mathrm{~m}$ in diameter (Figure 5). The second mound in this locality (SM-223) comprises a circular shell scatter with basal diameter of $20 \mathrm{~m}$ with a $0.2 \mathrm{~m}$ high portion of mounded deposit up to $5 \mathrm{~m}$ in diameter near the centre. Both SM-217 and SM223 have a surface shellfish composition that was primarily $T$. granosa, although other species including Geloina coaxans, Telescopium telescopium and Nerita spp. were also noted.
A second group of three distinct shell matrix deposits were observed on low-lying landforms adjacent to the Embley River, often in association with adjacent shell scatters of varying density and extent. These deposits occur on a series of narrow sand ridges that run east-west, at $10-20 \mathrm{~m}$ intervals. The two most seaward of these ridges converge into a single, broad ridge in the west and all of the mounds in this area are oriented along these narrow ridges. This is most evident with SM-218, which consists of a series of distinct mounds to $3 \mathrm{~m}$ in height running along several of these ridges (see Figure 4). The tallest mound, SM-220, is similar to SM-218 in that it is a large composite feature with a number of distinct peaks to about $3.5-4 \mathrm{~m}$ high and aligned with natural ridges, measuring $170 \mathrm{~m}$ long and up to $60 \mathrm{~m}$ wide, thus effectively fully covering the underlying ridge. The final feature, SM-219, is a small distinct mound located adjacent to a creek that runs parallel to the most northerly sand ridge. It is $<0.3 \mathrm{~m}$ in height and has a diameter of about $30 \mathrm{~m}$. Minor shell scatters occur in places along the ridge however heavy and impenetrable vegetation coverage prevented documentation of the extent of these.

\section{Stratigraphy and Chronology}

Excavation of SM-217 was carried out over a period of four days by a team of between two and six people. Test pit SM217 a was placed on the access track adjacent to the main mound, and yielded minimal cultural deposits which primarily consisted of minor amounts of $T$. granosa in a matrix of fine sand. The stratigraphy quickly transitioned to culturally sterile sands, and cultural deposits were very loosely compacted suggesting disturbance during clearing. These deposits add little to furthering the aims of this report, and as they have been reported elsewhere (Morrison 2005), here we focus on outlining results of work on the larger test pit, SM-217b.

Test pit SM-217b was $1 \mathrm{~m} \times 1 \mathrm{~m}$ in size, however this was reduced to $0.5 \mathrm{~m} \times 0.5 \mathrm{~m}$ at approximately $55 \mathrm{~cm}$ below the surface due to time constraints. The test pit was excavated to $83 \mathrm{~cm}$ below surface and abandoned when culturally sterile deposits were reached (Table 2). A stratigraphic section for the south wall of SM-217b (Figure 6) revealed a deposit principally composed of marine shell, with $T$. granosa most frequent, with higher proportions of Marcia hiantina evident in the mid-layers. Variations in shell fragmentation rates, sediment colour and proportions were the primary basis of defining stratigraphic layers, with the upper-most layers having characteristically high shell fragmentation and proportions of fine dark sediment while many lower layers appear to have lower sediment levels and shells which were less decayed or fragmented. An interesting feature of this mound is the high proportions of fine grey sediment, most likely ash, in some of the layers.

Three radiocarbon dates were obtained from the south wall of SM-217b (Figure 6), and calibrated age ranges indicate site formation commenced at around 722-906 cal BP (Wk-16364) (Table 3). A sample retrieved from the upper boundary of Layer 5 indicates that the lowermost deposits had accumulated prior to $433-565 \mathrm{cal} \mathrm{BP}$ (Wk-16363), or in the order of approximately 289-341 calendar years. A sample retrieved from near the surface returned a calibrated age span of 335-512 cal BP (Wk-16362), and is effectively contemporaneous with Wk-16363. Importantly, a substantial intrusion is evident in the southeast corner of the pit (Figure 6), with Layer 1 cutting into Layers 2-4. 
Table 1. Shell matrix deposits recorded at Mandjungaar. Note that site numbering follows that of the Albatross Bay Cultural Heritage Database (see Morrison 2013b).

\begin{tabular}{|l|l|l|l|l|r|r|r|r|}
\hline Site No. & \multicolumn{1}{|c|}{$\begin{array}{c}\text { Rio Tinto } \\
\text { ID }\end{array}$} & \multicolumn{1}{|c|}{ Type } & Morphology & \multicolumn{1}{|c|}{ Substrate } & $\begin{array}{c}\text { Length } \\
(\mathbf{m})\end{array}$ & $\begin{array}{c}\text { Width } \\
(\mathbf{m})\end{array}$ & $\begin{array}{c}\text { Height } \\
(\mathbf{m})\end{array}$ & $\begin{array}{c}\text { Basal Area } \\
(\mathbf{m})\end{array}$ \\
\hline SM-217 & WP-SM-31 & Mound & Dome & Dune/Sand Ridge & 40 & 30 & 1.2 & 774 \\
\hline SM-218 & WP-SM-32 & Mound & Composite & Dune/Sand Ridge & 110 & 30 & 4 & 1435 \\
\hline SM-219 & WP-SM-33 & Mound & Dome & Dune/Sand Ridge & 40 & 20 & 0.3 & 484 \\
\hline SM-220 & WP-SM-34 & Mound & Comosite & Dune/Sand Ridge & 170 & 60 & 3.5 & 5784 \\
\hline SM-221 & WP-SM-35 & Scatter & Scatter & Dune/Sand Ridge & 25 & 10 & 0 & 397 \\
\hline SM-222 & WP-SM-36 & Scatter & Scatter & Dune/Sand Ridge & 30 & 20 & 0 & 402 \\
\hline SM-223 & WP-SM-37 & Mound & Dome & Dune/Sand Ridge & 20 & 20 & 0.2 & 399 \\
\hline
\end{tabular}

Table 2. Excavated sediments, SM-217b. Note units without shading were excavated as a $1 \mathrm{~m} \times 1 \mathrm{~m}$ pit, while shaded cells represent units excavated as a $0.5 \mathrm{~m} \times 0.5 \mathrm{~m}$ pit.

\begin{tabular}{|c|c|c|c|c|c|}
\hline $\mathbf{X U}$ & $\begin{array}{c}\text { Cumulative Depth } \\
\text { Below Surface } \\
(\mathrm{cm})\end{array}$ & $\begin{array}{l}\text { Bulk Weight of } \\
\text { Sediment (kg) }\end{array}$ & $\begin{array}{l}\text { 7mm Residue } \\
\text { Weight (kg) }\end{array}$ & $\begin{array}{c}\text { 2mm Residue } \\
\text { Weight (kg) }\end{array}$ & Stones (g) \\
\hline 1 & 4 & 27.25 & 18.75 & 5 & 50 \\
\hline 2 & 7 & 25.75 & 21.82 & 5 & 5 \\
\hline 3 & 13 & 27.75 & 25.52 & 2.5 & 1 \\
\hline 4 & 18 & 27.5 & 27.5 & 1 & 0 \\
\hline 5 & 22 & 29.75 & 29.75 & 3 & 5 \\
\hline 6 & 27 & 27.5 & 25.73 & 3.5 & 10 \\
\hline 7 & 31 & 29.25 & 23.68 & 2.5 & 2 \\
\hline 8 & 38 & 34.6 & 26.13 & 2.5 & 0 \\
\hline 9 & 43 & 34.6 & 27.59 & 2.25 & 0 \\
\hline 10 & 55 & 17 & 13.47 & 1.25 & 0 \\
\hline 11 & 62 & 9.9 & 8.61 & 0.75 & 0 \\
\hline 12 & 75 & 14.9 & 9.62 & 3 & 0 \\
\hline 13 & 77 & 2.8 & 2.12 & 1.5 & 0 \\
\hline 14 & 83 & 2.4 & 1.42 & 1 & 19 \\
\hline
\end{tabular}

Table 3. Radiocarbon determinations and calibrated age spans, SM-217b.

\begin{tabular}{|c|r|c|r|r|c|}
\hline Lab. No. & \multicolumn{1}{|c|}{$\begin{array}{c}\text { Depth } \\
\text { (cm) }\end{array}$} & Sample & \multicolumn{1}{c|}{$\begin{array}{c}\boldsymbol{\delta}^{\mathbf{1 3}} \mathbf{C} \\
\mathbf{( \% )}\end{array}$} & $\begin{array}{c}{ }^{\mathbf{1 4}} \text { C Age } \\
\text { (years BP) }\end{array}$ & $\begin{array}{c}\text { Calibrated Age BP } \\
\mathbf{( 9 5 . 4 \% )}\end{array}$ \\
\hline Wk-16362 & 3.5 & T. granosa & -2.2 & $708 \pm 35$ & $335[423] 512$ \\
\hline Wk-16363 & 43.5 & T. granosa & -1.3 & $784 \pm 35$ & $433[499] 565$ \\
\hline Wk-16364 & 77 & T. granosa & -1.3 & $1167 \pm 35$ & $722[814] 906$ \\
\hline
\end{tabular}




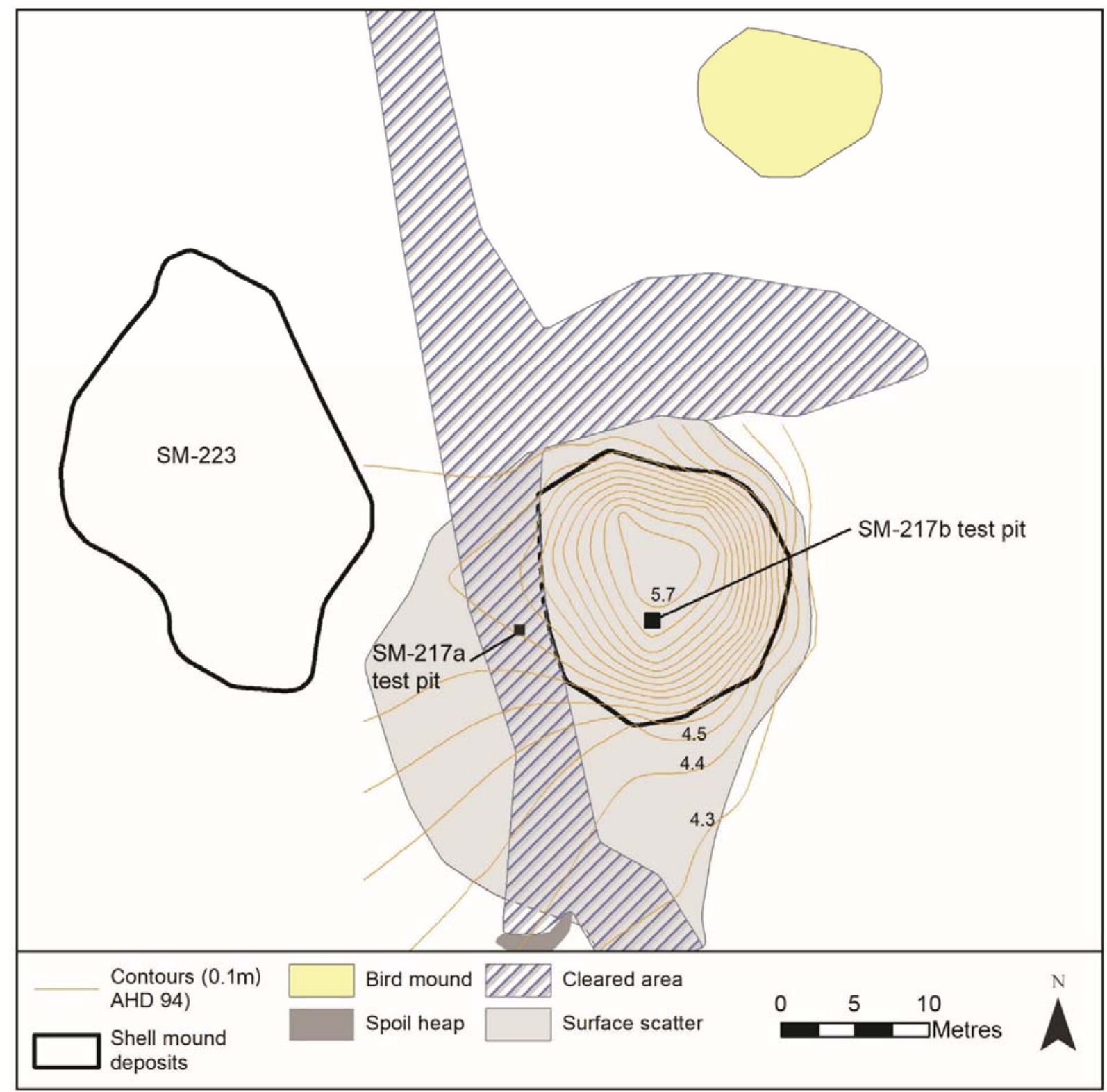

Figure 5. SM-217b site plan showing location of test pit and other features. 


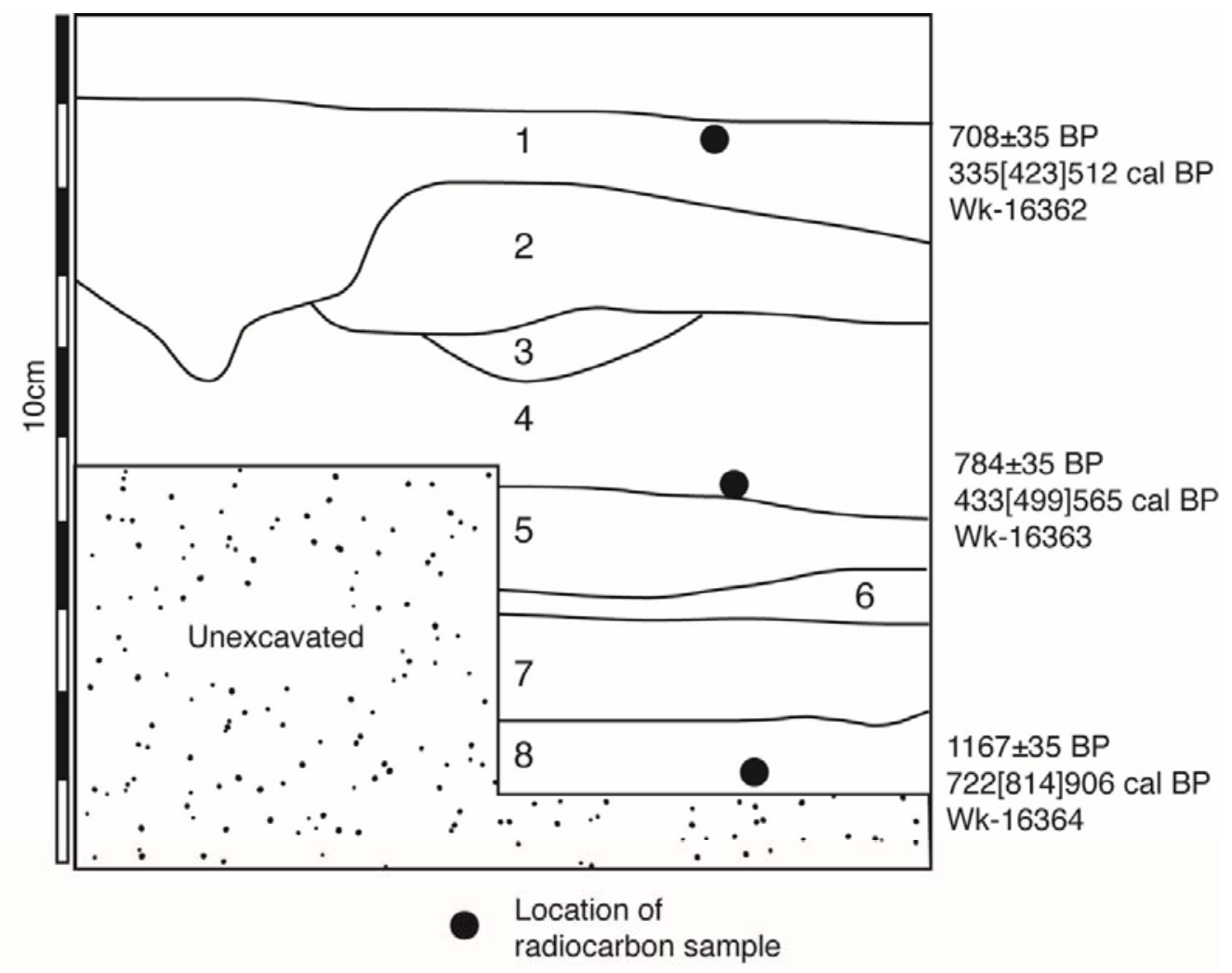

Stratigraphic Layer Descriptions

1. Dense, highly fragmented shell (white colouration) with high proportions of fine sediment including humic material. Frequent fine roots.

2. Dark friable soil with low proportions of fragmented and whole shell. Moderate proportions of fine roots.

3. Mostly whole shell (primarily $T$. granosa) in a matrix of fine grey ash. Few roots.

4. Mostly whole $T$. granosa shell (white colouration) with neglible fine sediment.

5. Mostly whole $T$. granosa shell (white colouration) with increasing proportion of fine dark sediment.

6 . Discrete lense of small shell fragments $(<2 \mathrm{~cm})$ and fine grey ashy sediment

7. Mostly whole $T$. granosa shell with moderate proportions of fine dark sediment, transitioning to fine sandy sediment.

8 . Fine sandy sediment lacking shell

Figure 6. SM-217b section drawing, south wall. 


\section{Cultural Materials}

While pit SM-217b pit was rich in shellfish remains, only small numbers of other cultural materials were identified. These included four small fragments of flaked stone, two fish otoliths, one fragment of compacted sediment identified as ant bed, several small fragments of crab, and a small amount of fragmented bone (Table 4). Most of these materials were recovered between $27 \mathrm{~cm}$ and $55 \mathrm{~cm}$ below surface in excavation units 6-10, and which are associated with stratigraphic layers 3, 4 and 5 (Figure 6). The majority of bone material recovered was post-cranial and fragmented, and therefore considered unsuitable for identification purposes. The stone artefacts were very small, ranging between 8$18 \mathrm{~mm}$ in length (Table 5), and included three made from quartz and one from silcrete. Quartz is locally available on erosional surfaces at the margins of the bauxite plateau. Silcrete is likely to have been obtained to the east in the foothills of the Great Dividing Range and associated streams.

\section{Molluscan Fauna}

Shellfish remains were the most abundant cultural material recovered, with $T$. granosa the most regularly-occurring species by MNI. This is particularly the case in the upper five excavation units, where this species consistently represents over $89 \%$ of the total unit MNI (Table 6). Below XU6, there is a clear drop in the relative abundance of T. granosa along with an increase in the proportions of $M$. hiantina, which is less than $11 \%$ of unit MNI for the upper six units, increasing to $20.9-36.1 \%$ near the middle of the deposit (Figure 7). Other species (Geloina coaxans, Saccostrea cucullata, Nerita balteata, Telescopium telescopium, Terebralia palustris, Volegalea cochlidium and Balanus balanus) are present in very low proportions throughout the deposit (Table 6), with proportions peaking in the uppermost two units, representing $2.7-3.7 \%$ of total unit MNI due to an increased number of Geloina coaxans, but remaining $<1.5 \%$ for all other units.

\section{Discussion}

The large shell scatters present in this mound complex (SM221, SM-222) are similar to what Morrison (2013a:180) has classified as incipient mounds. This involves concentrated shellfish processing and deposition around a central place creating a broad discrete surface deposit of shell, but at insufficient intensity to form a discrete mound. It is also possible that past ground disturbance may have altered the distribution of surface shell in the vicinity of these low density scatters. Other shell matrix features are more consistent with intermediate mounds (SM-219, SM-223), whereby ongoing shell deposition has led to the formation of a broad discrete mound that is low in height $(<30 \mathrm{~cm})$. The remaining sites (SM-217, SM-218, SM-220) are representative of classic mound deposits, with varied depositional and taphonomic histories.

People appear to have begun constructing the SM-217 mound at around $\sim 800$ cal BP, continuing through until at least $\sim 400-500$ cal BP. Importantly, determinations on the upper and middle portions of the deposit are essentially contemporaneous. Stratigraphic discontinuities are considered the likely cause of this, with some evidence for older deposits having been reworked onto the mound surface as suggested by the section profile for the south wall of the deposit (Figure 6), which shows Layer 1 cutting through into
Layers 2 and 4 . The full extent and precise cause of this large area of disturbance is of course unknown, however, given the size of the intrusion it is feasible that it was caused by a tree falling over with some of the root system lifting and displacing adhering sediments. This highlights the importance of stratigraphic analysis to the interpretation of radiocarbon determinations for these sites. As such, the calibrated age ranges for the uppermost radiocarbon samples provide only a conservative estimate for cessation of mound building. The presence of steel axe-cut culturally modified trees, along with oral historical and documentary sources, clearly indicate continued use of this locality during the 1930s. Indeed, the presence of scarred trees of a likely post-contact age in close association with shell mounds is also strongly suggestive of continued use of the mound complex itself in the post-contact period. As such, it is likely that shell matrix site formation continued in this area until the early contact period, when there was a major transformation in regional economies and settlement patterns, and characterised by short-duration forays from mission settlements (Morrison 2010; Morrison and Shepard 2013; Morrison et al. 2015). While there is no direct evidence of post-contact use of mound sites at Mandjungaar, elsewhere in the region there are indications of post-contact use of shell and earth mounds as indicated by the presence of modified glass on and within mound deposits (Morrison 2015; Ó Foghlú et al. 2016).

Shellfish remains are the most frequently occurring type of cultural material recovered in SM-217b, although a range of other materials including fragmented vertebrate fauna, crab claws, stone artefacts and fish otoliths were found in very small numbers. The dominant species of shellfish is $T$. granosa, comprising $63-98 \%$ by MNI of the deposit. $M$. hiantina is the next most frequently occurring species, at times comprising up to $36 \%$ of the shellfish composition. A wide range of other species are present, but these make up less than $4 \%$ of the shellfish composition in any layer. This is a very similar pattern to other sites excavated and reported in the region, such as Prunung, Bweening and Kwamter (Bailey 1977, 1994; Morrison 2013a, 2015) where T. granosa is the most abundant species in mounds. These results therefore expand the applicability of previously proposed niche production hypothesis (Morrison 2013b) in the Weipa region. This posits that mounds reflect an economic strategy characterised by dynamic and strategic use of niche estuarine ecosystems and focussed on intertidal flats at times where $r$ selected species such as T. granosa were abundant.

\section{Conclusion}

Results of research at Mandjungaar add to the wider understanding of the archaeology of the Weipa Peninsula and the Albatross Bay region more generally, and provide a useful comparative assemblage that helps link results of more intensive work undertaken at both Kwamter and Wathayn. However, these results only provide a preliminary indication of shell matrix chronology for this locality. Other shell matrix deposits also occur nearby, and some of these are very large and complex features with evident variability in composition as revealed by inspection of areas of disturbed sediment on these sites. As others have noted, isolated sampling of mounds across localities with such considerable levels of shell deposition are insufficient for drawing firm conclusions about wider patterns of mound cluster formation and use (Bailey 1999; Holdaway et al. 2017). 
Table 4. Non-molluscan cultural materials recovered from SM-217b. Note units without shading were excavated as a $1 \mathrm{~m} \times 1 \mathrm{~m}$ pit, while shaded cells represent units excavated as a $0.5 \mathrm{~m} \times 0.5 \mathrm{~m}$ pit.

\begin{tabular}{|c|r|r|r|l|l|l|}
\hline XU & \multicolumn{2}{|c|}{$\begin{array}{c}\text { Stone } \\
\text { Artefacts }\end{array}$} & Bone & Otoliths & Crab & Antbed \\
\hline & (\#) & (g) & (g) & (\#) & (g) & (g) \\
\hline 1 & & & & & & \\
\hline 2 & & & & & & \\
\hline 3 & & & & & & \\
\hline 4 & & & & & & \\
\hline 5 & & & & & & \\
\hline 6 & & & 1 & & & \\
\hline 7 & 1 & 2 & 1 & & & \\
\hline 8 & 1 & 4 & 2 & & & \\
\hline 9 & 1 & 2 & 10 & & & \\
\hline 10 & 1 & 4 & & & & \\
\hline 11 & & & & & & \\
\hline 12 & & & & & & \\
\hline 13 & & & & & & \\
\hline 14 & & & & & & \\
\hline
\end{tabular}

Table 5. Summary data on stone artefacts recovered from SM-217b.

\begin{tabular}{|c|l|r|r|r|}
\hline XU & Raw Material & \multicolumn{1}{c|}{$\begin{array}{c}\text { Length } \\
(\mathbf{m m})\end{array}$} & $\begin{array}{l}\text { Width } \\
\text { (mm) }\end{array}$ & \multicolumn{1}{c|}{$\begin{array}{c}\text { Thickness } \\
\text { (mm) }\end{array}$} \\
\hline 7 & Quartz & 8 & 7 & 3 \\
\hline 8 & Silcrete & 18 & 9 & 9 \\
\hline 9 & Quartz & 15 & 12 & 11 \\
\hline 10 & Quartz & 15 & 7 & 5 \\
\hline
\end{tabular}

Table 6. Molluscan fauna recovered from SM-217b. Estimated total T. granosa MNI values were calculated from a subsample retrieved during excavation (see Methods section for additional details). Note units without shading were excavated as a $1 \mathrm{~m} \times 1 \mathrm{~m}$ pit, while shaded cells represent units excavated as a $0.5 \mathrm{~m} \times 0.5 \mathrm{~m}$ pit.

\begin{tabular}{|c|c|c|c|c|c|c|c|c|c|}
\hline \multirow[b]{3}{*}{$\mathbf{X U}$} & \multicolumn{5}{|c|}{ Minimum Number of Individuals (MNI) } & \multicolumn{3}{|c|}{ Proportion of Unit Total MNI } & \multirow{3}{*}{$\begin{array}{c}\text { Estimated } \\
\text { XU MNI }\end{array}$} \\
\hline & \multicolumn{3}{|c|}{ T. granosa } & \multirow[b]{2}{*}{ M. hiantina } & \multirow[b]{2}{*}{$\begin{array}{c}\text { Other } \\
\text { Species }\end{array}$} & \multirow[b]{2}{*}{ T. granosa } & \multirow[b]{2}{*}{ M. hiantina } & \multirow[b]{2}{*}{$\begin{array}{c}\text { Other } \\
\text { Species }\end{array}$} & \\
\hline & $\begin{array}{c}\text { Sub- } \\
\text { sample } \\
\text { (MNI) }\end{array}$ & $\begin{array}{c}\text { Sub- } \\
\text { sample } \\
(\%)\end{array}$ & $\begin{array}{l}\text { Estimated } \\
\text { Total MNI }\end{array}$ & & & & & & \\
\hline 1 & 210 & 22 & 940 & 22 & 37 & 94.1 & 2.2 & 3.7 & 998 \\
\hline 2 & 251 & 20 & 950 & 33 & 27 & 94.1 & 3.2 & 2.7 & 1009 \\
\hline 3 & 281 & 20 & 1158 & 30 & 17 & 96.1 & 2.5 & 1.4 & 1204 \\
\hline 4 & 304 & 20 & 1315 & 19 & 14 & 97.6 & 1.4 & 1.0 & 1348 \\
\hline 5 & 308 & 20 & 1307 & 48 & 9 & 95.8 & 3.5 & 0.7 & 1364 \\
\hline 6 & 319 & 20 & 1040 & 127 & 1 & 89.0 & 10.9 & 0.1 & 1168 \\
\hline 7 & 298 & 22 & 1053 & 319 & 3 & 76.6 & 23.2 & 0.2 & 1375 \\
\hline 8 & 332 & 21 & 1102 & 630 & 14 & 63.1 & 36.1 & 0.8 & 1745 \\
\hline 9 & 340 & 20 & 1148 & 441 & 8 & 71.9 & 27.6 & 0.5 & 1596 \\
\hline 10 & 641 & 100 & 641 & 170 & 1 & 79.0 & 20.9 & 0.1 & 811 \\
\hline 11 & 818 & 100 & 818 & 31 & 0 & 96.3 & 3.7 & 0.0 & 849 \\
\hline 12 & 587 & 100 & 587 & 113 & 3 & 83.5 & 16.1 & 0.4 & 703 \\
\hline 13 & 153 & 100 & 153 & 0 & 0 & 100.0 & 0.0 & 0.0 & 153 \\
\hline 14 & 130 & 100 & 130 & 24 & 2 & 83.3 & 15.4 & 1.3 & 156 \\
\hline
\end{tabular}




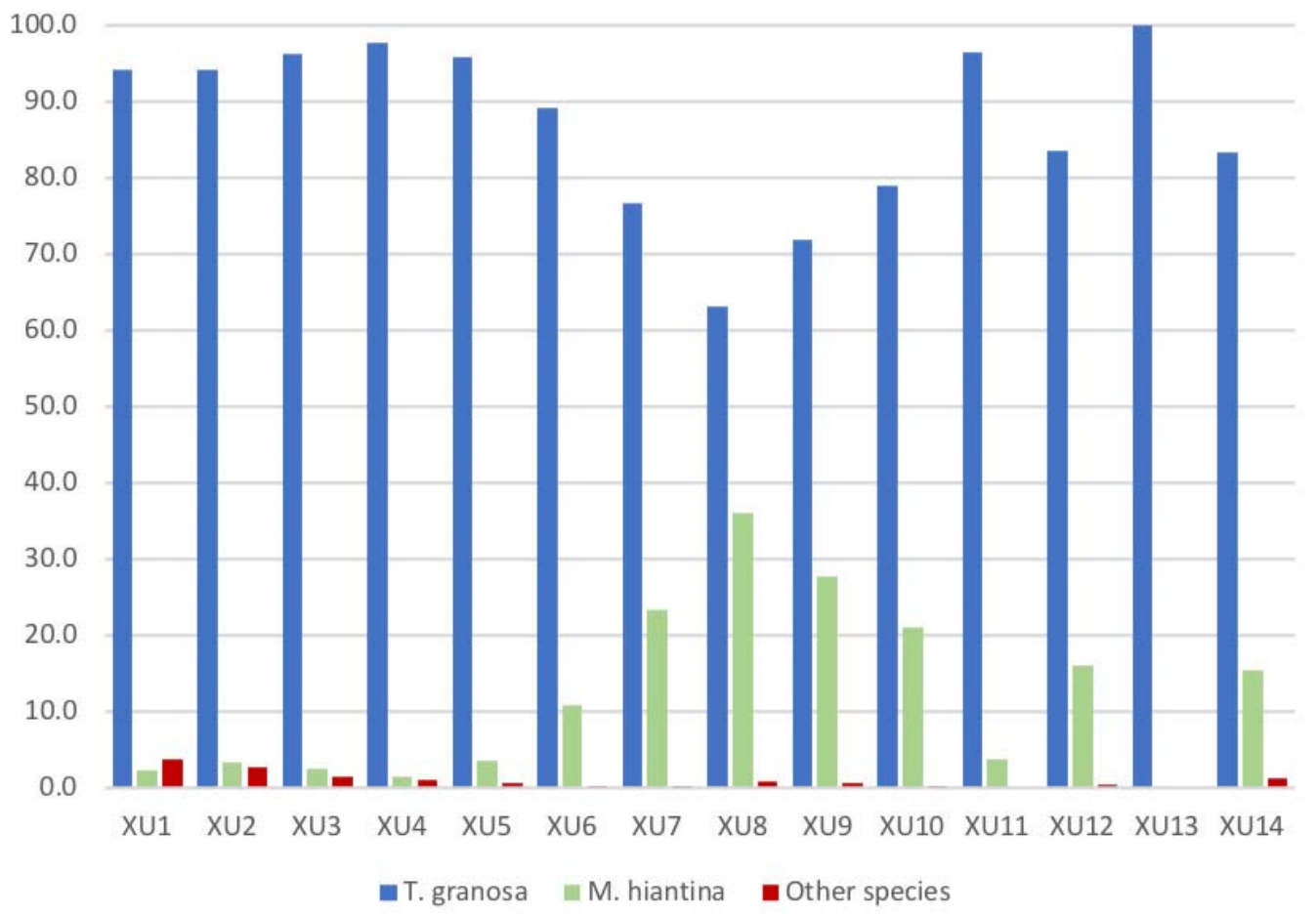

Figure 7. SM-217b shellfish MNI as a percentage of total unit shellfish MNI. Other species include Geloina coaxans, Saccostrea cucullata, Nerita balteata, Telescopium telescopium, Terebralia palustris, Volegalea cochlidium and Balanus balanus.

This project has further established that shell mound deposits in the Albatross Bay catchment are predominantly composed of r-selected species such as T. granosa, which are prone to forming high resource biomass within estuarine systems during optimal conditions. These results add support to previous suggestions (Morrison 2013a, 2013b, 2015) that mound formation was tied to food production strategies that were heavily focused on specific ecological niches, namely estuarine mudflats, with little evidence of any significant use of terrestrial resources. This has been argued to be reflective of wider settlement systems whereby people strategically targeted particular ecological niches at varying levels of intensity. This does not necessarily imply that all mounds are the result of large-scale intensive harvesting activities (cf. Holdaway et al. 2017), but instead, that the scale of these shellfish harvesting events were scaled up or down in line with resource availability. That said, to date, little attention has been afforded to understanding taphonomic processes that might impact on vertebrate faunal preservation on mound sites in northern Australia, and this remains a key issue to be resolved if more anthropologically-oriented questions about the formation, use and significance of mound deposits are to be advanced. It is also intriguing that the ethnohistorical data reported here indicates a consistent preference for use of this locality during the early wet season, and this may be suggestive of an earlier pre-colonial preference of using this region at this time of year. Obtaining independent data on the season of site use is necessary to test this hypothesis, and relatively new approaches to sclerochronology (Twaddle et al. 2016) provide important opportunities for furthering our understanding of the seasonality of site use, and the wider role of mound sites within regional settlement patterns and economies.

\section{Acknowledgements}

We gratefully acknowledge the support and input of a range of Ndrua'angayth custodians who initiated this project and who permitted us to work on their Country. These included Mrs Beatrice Gordon, Mrs Thelma Coconut and Mr Stanley Coconut, as well as a number of other community members who assisted with fieldwork. Funding and support with field logistics for this project was provided by Comalco Aluminium Ltd, and we thank Dr Justin Shiner in particular for supporting and facilitating this study. Finally, Napranum Council Indigenous Land and Sea Rangers contributed to the fieldwork, particularly Senior Ranger Richard Barkley who assisted with field surveys. We also thank the three anonymous reviewers for their constructive and generous feedback, which have improved the final manuscript.

\section{References}

Bailey, G.N. 1975 The Role of Shell Middens in Prehistoric Economies. Unpublished $\mathrm{PhD}$ thesis, University of Cambridge, Cambridge.

Bailey, G.N. 1977 Shell mounds, shell middens, and raised beaches in the Cape York Peninsula. Mankind 11(2):132-143. https://doi.org /10.1111/j.1835-9310.1977.tb01175.x

Bailey, G.N. 1993 Shell mounds in 1972 and 1992: Reflections on recent controversies at Ballina and Weipa. Australian Archaeology 37:1-18. https://doi.org/10.1080/03122417.1993.11681491

Bailey, G.N. 1994 The Weipa shell mounds: Natural or cultural. In M. Sullivan, S. Brockwell and A. Webb (eds), Archaeology in the North: Proceedings of the 1993 Australian Archaeological Association Conference, pp.107-129. Darwin: North Australia Research Unit, Australian National University. 
Bailey, G.N. 1999 Shell mounds and coastal archaeology in northern Queensland. In J. Hall and I.J. McNiven (eds), Australian Coastal Archaeology, pp.105-112. Research Papers in Archaeology and Natural History 31. Canberra: Archaeology and Natural History Publications, Research School of Pacific and Asian Studies, Australian National University.

Bourke, P.M. 2005 Archaeology of shell mounds of the Darwin coast: Totems of an ancestral landscape. In P.M. Bourke, S. Brockwell and C. Fredericksen (eds), Darwin Archaeology: Aboriginal, Asian and European Heritage of Australia's Top End, pp.29-48. Darwin: Charles Darwin University Press.

Bourke, P. 2012 Late Holocene Indigenous Economies of the Tropical Australian Coast: An Archaeological Study of the Darwin Region. British Archaeological Reports International Series 2340. Oxford: Archaeopress.

Brockwell, S., B. Ó Foghlú, J.N. Fenner, J. Stevenson, U. Proske and J. Shiner 2017 New dates for earth mounds at Weipa, north Queensland, Australia. Archaeology in Oceania 52(2):127-134. https://doi.org/10.1002/arco.5118

Cribb, R.L. 1996 The Comalco Agreement Project: Aboriginal Cultural Heritage Study. Unpublished report to Cape York Land Council and the Project Steering Committee, Cairns, Queensland.

Fanning, P.C., S.J. Holdaway and K. Allely 2018 Geoarchaeology in action: A sedimentological analysis of anthropogenic shell mounds from the Cape York region of Australia. Quaternary International 463:44-56. https://doi.org/10.1016/i.quaint.2016.09.010

Faulkner, P. 2009 Focused, intense and long-term: Evidence for granular ark (Anadara granosa) exploitation from late Holocene shell mounds of Blue Mud Bay, northern Australia. Journal of Archaeological Science 36(3):821-834. https://doi.org/10.1016 /j.jas.2008.11.005

Faulkner, P. 2013 Life on the Margins: An Archaeological Investigation of Late Holocene Economic Variability, Blue Mud Bay, Northern Australia. Terra Australis 38. Canberra: ANU E Press.

Holdaway S.J., P.C. Fanning, F. Petchey, K. Allely, J.I. Shiner and G. Bailey 2017 Temporal variability in shell mound formation at Albatross Bay, northern Australia. PLOS ONE 2(8):e0183863. https://doi.org/10.1371/journal.pone.0183863

Luly, J.G., J.F. Grindrod and D. Penny 2006 Holocene palaeoenvironments and change at Three-Quarter Mile Lake, Silver Plains Station, Cape York Peninsula, Australia. The Holocene 16(8):1085-1094. https://doi.org/10.1177/0959683606069398

McKay, S.E. 1934 Weipa Mission Station Diary, 1st January 1934 to 31st December 1934. Unpublished diary, Cape York Collection, Hibberd Library, Weipa.

McKay, S.E. 1935 Weipa Mission Station Diary, 1st January 1935 to 31st December 1935. Unpublished diary, Cape York Collection, Hibberd Library, Weipa.

Morrison, M. 2003 Old boundaries and new horizons: the Weipa shell mounds reconsidered. Archaeology in Oceania 38(1):1-8. https://doi.org/10.1002/j.1834-4453.2003.tb00516.x

Morrison, M.J. 2005 Results of Archaeological Excavations and Analysis of Damaged Shell Midden, Whiting Mine (Mandjungaar). Unpublished report to Comalco Aluminium Limited, Weipa.

Morrison, M. 2010 The Shell Mounds of Albatross Bay: An Archaeological Investigation of Late Holocene Production Strategies near Weipa, North Eastern Australia. Unpublished PhD thesis, Flinders University, Adelaide.

Morrison, M. 2013a From scatter to mound: A new developmental model for shell mound sites at Weipa. Queensland Archaeological Research 16:165-184. http://dx.doi.org/10.25120/qar.16.2013.228
Morrison, M. 2013b Niche production strategies and shell matrix site variability at Albatross Bay, Cape York Peninsula. Archaeology in Oceania 48(2):78-91. https://doi.org/10.1002/arco.5002

Morrison, M. 2014 Chronological trends in late Holocene shell mound construction across northern Australia: Insights from Albatross Bay, Cape York Peninsula. Australian Archaeology 79:113. https://doi.org/10.1080/03122417.2014.11682014

Morrison, M. 2015 Late Holocene Aboriginal shellfish production strategies in northern Australia: Insights from Prunung (Red Beach), Weipa, Cape York Peninsula. Queensland Archaeological Research 18:1-27. http://dx.doi.org/10.25120/qar.18.2015.3498

Morrison, M., D. McNaughton and C. Keating 2015 "Their God is their belly": Moravian missionaries at the Weipa Mission (18981932), Cape York Peninsula. Archaeology in Oceania 50(2):85-104. https://doi.org/10.1002/arco.5061

Morrison, M., D. McNaughton and J. Shiner 2010 Mission-based Indigenous production at the Weipa Presbyterian Mission, western Cape York Peninsula (1932-66). International Journal of Historical Archaeology 14(1):86-111. https://doi.org/10.1007/s10761-0090096-8

Morrison, M. and E. Shepard 2013 The archaeology of culturally modified trees: Indigenous economic diversification within colonial intercultural settings in Cape York Peninsula, northeastern Australia. Journal of Field Archaeology 38(2):143-160. https://doi.org $\underline{10.1179 / 0093469013 Z .00000000044}$

Ó Foghlú, B., D. Wesley, S. Brockwell and H. Cooke 2016 Implications for culture contact history from a glass artefact on a Diingwulung earth mound in Weipa. Queensland Archaeological Research 19:1-22. http://dx.doi.org/10.25120/qar.19.2016.3499

Petchey, F., S. Ulm, B. David, I.J. McNiven, B. Asmussen, H. Tomkins, N. Dolby, K. Aplin, T. Richards, C. Rowe, M. Leavesley and H. Mandui. 2013 High-resolution radiocarbon dating of marine materials in archaeological contexts: Radiocarbon marine reservoir variability between Anadara, Gafrarium, Batissa, Polymesoda spp. and Echinoidea at Caution Bay, southern coastal Papua New Guinea. Archaeological and Anthropological Sciences 5(1):69-80. https://doi.org/10.1007/s12520-012-0108-1

Reimer, P.J., E. Bard, A. Bayliss, J.W. Beck, P.G. Blackwell, C.B. Ramsey, C.E. Buck, H. Cheng, R.L. Edwards, M. Friedrich, P.M. Grootes, T.P. Guilderson, H. Haflidason, I. Hajdas, C. Hatté, T.J. Heaton, D.L. Hoffmann, A.G. Hogg, K.A. Hughen, K.F. Kaiser, B. Kromer, S.W. Manning, M. Niu, R.W. Reimer, D.A. Richards, E.M. Scott, J.R. Southon, R.A. Staff, C.S.M Turney and J. van der Plicht 2013 IntCal13 and Marine13 radiocarbon age calibration curves 0 50,000 years cal BP. Radiocarbon 55(4):1869-1887. https://doi.org $\underline{10.2458 / \text { azu is re. } 55.16947}$

Rhodes, E.G., H.A. Polach, B.G. Thom and S.R. Wilson 1980 Age structure of Holocene coastal sediments: Gulf of Carpentaria, Australia. Radiocarbon 22(3):718-727. https://doi.org/10.1017 /S0033822200010080

Shiner J.I., P.C. Fanning, S.J. Holdaway, F. Petchey, C. Beresford, E. Hoffman and B. Larsen 2013 Shell mounds as the basis for understanding human-environment interaction in far North Queensland, Australia. Queensland Archaeological Research 16:65-91. http://dx.doi.org/10.25120/qar.16.2013.224

Shiner, J. and M. Morrison 2009 The contribution of heritage surveys towards understanding the cultural landscape of the Weipa bauxite plateau. Australian Archaeology 68:52-55. https://doi.org/10.1080 /03122417.2009.11681890

Smith, A. 2016 Archaeological Expressions of Holocene Cultural and Environmental Change in Coastal Southeast Queensland. Unpublished $\mathrm{PhD}$ thesis, School of Social Science, University of Queensland, Brisbane. 
Stephens, K. and L. Head 1995 Paleoecology of archaeological and swamp sites in S.E. Cape York Peninsula. In M.J. Morwood and D.R. Hobbs (eds), Quinkan Prehistory: The Archaeology of Aboriginal Art in S.E. Cape York Peninsula, Australia, pp.18-32. Tempus 3. St Lucia, QLD: Anthropology Museum, University of Queensland.

Stevenson, J., S. Brockwell, C. Rowe, U. Proske and J. Shiner 2015 The palaeo-environmental history of Big Willum Swamp, Weipa: An environmental context for the archaeological record. Australian Archaeology 80:17-31. https://doi.org/10.1080/03122417.2015 .11682041

Stone, T. 1992 Origins of the Weipa Shell Mounds. Unpublished MSc thesis, Australian National University, Canberra.

Stone, T. 1995 Shell mound formation in coastal northern Australia. Marine Geology 129(1-2):77-100. https://doi.org/10.1016/0025$\underline{3227(95) 00101-8}$

Stuiver, M., P.J. Reimer and R.W. 2005 CALIB 5.0 [WWW program]. Accessed 17 November 2017 at http://calib.org/calib/.

Sutton, P. 1994 Material culture traditions of the Wik peoples, Cape York Peninsula. Records of the South Australian Museum 27:31-52.

Twaddle, R.W., S. Ulm, J. Hinton, C.M. Wurster and M.I. Bird 2016 Sclerochronological analysis of archaeological mollusc assemblages: Methods, applications and future prospects. Archaeological and Anthropological Sciences 8(2):359-379. https://doi.org/10.1007/s12520-015-0228-5

Ulm, S. 2002 Marine and estuarine reservoir effects in central Queensland, Australia: Determination of $\Delta \mathrm{R}$ values. Geoarchaeology 17(4):319-348. https://doi.org/10.1002/gea.10017

Ulm, S. 2010 Marine Carbon Reservoir Variability in the Southern Gulf of Carpentaria: Progress Report for AINGRA09025. Accessed 23 April 2018 from http://ainse.edu.au/_data/assets/pdf file 10011/48638/r_09025.pdf.
Ulm, S. 2011 Coastal foragers on southern shores: Marine resource use in northeast Australia since the late Pleistocene. In N.F. Bicho, J.A. Haws and L.G. Davis (eds), Trekking the Shore: Changing Coastlines and the Antiquity of Coastal Settlement, pp.441-461. Interdisciplinary Contributions to Archaeology. New York: Springer. https://doi.org/10.1007/978-1-4419-8219-3_19

Veitch, B. 1999 Shell middens on the Mitchell Plateau: A reflection of a wider phenomenon? In J. Hall and I. McNiven (eds), Australian Coastal Archaeology, pp.51-64. Research Papers in Archaeology and Natural History 31. Canberra: Archaeology and Natural History Publications, Research School of Pacific and Asian Studies, Australian National University.

Winn, J. 1936 Weipa Mission Station Diary, 1st January 1936 to 31st December 1936. Unpublished diary, Cape York Collection, Hibberd Library, Weipa.

Wright, R.V.S. 1963 Report on Archaeological Reconnaissance Work in Cape York. Unpublished report to Australian Institute of Aboriginal Studies, Canberra.

Wright, R.V.S. 1971 Prehistory in the Cape York Peninsula. In D.J. Mulvaney and J. Golson (eds), Aboriginal Man and Environment in Australia, pp.133-140. Canberra: Australian National University Press.

Citation: Morrison, M., C. Wight and E. Evans 2018 Report on excavation of a shell mound site at Mandjungaar, western Cape York Peninsula. Queensland Archaeological Research 21:13-26. https://doi.org/10.25120/qar.21.2018.3637 